\title{
A new species of Tambja (Mollusca, Gastropoda, Nudibranchia) from the Mediterranean Sea: description of the first species of the genus from the Balearic Islands and Malta
}

\author{
M. Domínguez ${ }^{1} \cdot$ M. Pola ${ }^{2} \cdot$ M. Ramón ${ }^{1,3}$
}

Received: 8 August 2014/Revised: 1 March 2015/Accepted: 5 March 2015/Published online: 27 March 2015

(C) Springer-Verlag Berlin Heidelberg and AWI 2015

\begin{abstract}
A new species of polycerid nudibranchs of the genus Tambja is described from Mallorca Island (Spain) and Malta. So far, only two species of Tambja had been recorded in the Mediterranean Sea with a distribution limited to southern Spain. With Tambja mediterranea sp. nov., the distribution of the genus in the Mediterranean Sea is extended, and the new species represents the first occurrence of Tambja at the Balearic Islands and Malta. Externally, the new species is mainly characterized by having ground orange-red colour, dorsum covered with rounded whitish tubercles, rhinophores red with whitish tips and three gill branches with orange-reddish rachis and whitish branches. In the present paper, external and internal features of $T$. mediterranea are described and compared with other species of the genus, especially with its most similar species, T. limaciformis. Additionally, phylogenetic analyses (Bayesian and maximum likelihood) based on mitochondrial sequences (COI) show that $T$. mediterranea sp. nov. is sister to $T$. divae and that both species cluster
\end{abstract}

Communicated by H.-D. Franke.

M. Domínguez

malvarezgal@yahoo.es

M. Pola

mpolaperez@gmail.com

M. Ramón

mramon@icm.csic.es

1 Centro Oceanográfico de Baleares, Instituto Español de Oceanografía, Moll de Ponent, s/n, 07015 Palma, Spain

2 Departamento de Biología, Edificio de Biología, Universidad Autónoma de Madrid, Campus de Excelencia Internacional UAM+CSIC, C/Darwin, 2, 28049 Madrid, Spain

3 Institut de Ciències del Mar (CSIC), Passeig Marítim de la Barceloneta, 37-49, 08003 Barcelona, Spain together with $T$. limaciformis and T. amakusana with the maximum support.

Keywords Polyceridae $\cdot$ Nembrothinae $\cdot$ Mediterranean Sea $\cdot$ New species $\cdot$ Balearic Island $\cdot$ Malta

\section{Introduction}

The genus Tambja Burn, 1962 is one of the three genera of the subfamily Nembrothinae Burn (1967), the others being Nembrotha Bergh, 1877 and Roboastra Bergh, 1877 (Burn 1967). In the last decade, morphological and molecular analyses have shown that the phylogenetic relationships of Nembrothinae are still unresolved and that Nembrotha is the only genus so far verified to be monophyletic (Pola et al. 2006a, b, 2007, 2008). However, the taxonomical changes proposed by Pola et al. (2007) have not been implemented yet, and it is clear that further analyses comprising all described and still undescribed species of the subfamily are crucial to fully understand the phylogenetic relationship within the subfamily Nembrothinae (Pola et al. 2007, 2008).

Traditionally, the genus Tambja s.l. Burn, 1962 has been characterized by the presence of a thick and smooth labial cuticle, rectangular rachidian radular tooth with notched or smooth upper margin, lateral tooth bifid or with a simple cusp, and three to seven marginal plates. In addition, the prostate gland is small and confined to a glandular section of the vas deferens, and the penis is armed (Burn 1967; Pola et al. 2006a). However, Pola et al. (2006a, b, c, 2007, 2008) have shown that some "Tambja" species are quite different (Table 1). For instance, Tambja limaciformis (Eliot 1908), T. amakusana (Baba 1987) and T. divae (Marcus, 1958) have lateral pouches located between the 
Table 1 "Unusual" features found in some species of "Tambja" s.1. Burn, 1962

\begin{tabular}{llllll}
\hline & Lateral pouches & Vestigial teeth & Vaginal gland & Prostate surrounds bursa copulatrix & Wide vagina \\
\hline Tambja capensis (Bergh, 1907) & No & Yes & Yes & No & No \\
T. limaciformis (Eliot 1908) & Yes & Yes & No & Yes & Yes \\
T. divae (Er. Marcus, 1958) & Yes & No & No & Yes & Yes \\
T. abdere Farmer, 1978 & No & No & No & Yes & No \\
T. amakusana (Baba 1987) & Yes & Yes & No & Yes & Yes \\
T. blacki Pola et al. (2006a) & No & No & No & Yes & Yes \\
T. mediterranea sp. nov. & Yes & No & No & Yes & \\
\hline
\end{tabular}

oral tube and the buccal bulb; T. limaciformis, T. amakusana and T. capensis (Bergh, 1907) have vestigial teeth between the rachidian and the inner lateral teeth. In addition, T. limaciformis, T. amakusana, T. divae, T. blacki Pola et al. 2006a and T. abdere Farmer, 1978 have a quite different arrangement of the reproductive system (see "Discussion").

To date, 27 valid species of the genus Tambja have been described worldwide, but many others are still undescribed (e.g. Nakano 2004; Cobb and Willan 2006; Debelius and Kuiter 2007; Coleman 2008; Gosliner et al. 2008), or in the process of being described Pola et al. (2014). Most of them have been recorded in the Indo-Pacific, but the geographical distribution of Tambja includes the Atlantic Ocean, the eastern Pacific and the Galápagos Islands (Pola et al. 2006a). Two species, T. ceutae García-Gómez and Ortea 1988 and T. marbellensis Schick and Cervera (1998), have been recorded in the Alborán Sea (Cervera et al. 2004). To date, the distribution of the genus in the Mediterranean Sea is limited to this area of southern Spain next to the Strait of Gibraltar.

In the present paper, we describe a new species of "Tambja" s.l. Burn, 1962 from Mallorca Island and Malta, Tambja mediterranea sp. nov. This is the first record of the genus for the Balearic Islands and Malta and the only known species of the genus in this part of the Mediterranean Sea. We compare and discuss the new species with other species of the genus "Tambja" s.l. Burn, 1962.

\section{Materials and methods}

In July 2012, six specimens of Tambja sp. nov. were found in southern Mallorca (Balearic Islands, Spain) and two specimens in July 2014 in Fomm Ir-Rih Bay (Malta). The sea slugs from Mallorca were found in one out of 41 samples collected on board of the RV Ramón Margalef, as part of a study focused on mapping the benthic habitats of the continental shelf between Sa Dragonera and Cabrera (DRAGONSAL Project). The sample was collected at $53 \mathrm{~m}$ depth, in a medium-grained sandy bottom, in a zone located in front of the municipality of Llucmajor, eastern Bay of Palma $\left(39^{\circ} 18^{\prime} 18.5^{\prime \prime} \mathrm{N}, 02^{\circ} 47^{\prime} 50.8^{\prime \prime} \mathrm{E}\right)$. Sampling was performed using a beam trawl of $2 \mathrm{~m}$ width provided with a cod end of $20 \mathrm{~mm}$ mesh size, which was trawled for 3 min at 2 knots. The sample was predominantly composed by the red algae Phyllophora crispa. Once on board, the sample was washed to eliminate the sediment and the taxonomic groups were separated for the identification of algae and fauna species. Specimens from Malta $\left(35^{\circ} 54^{\prime} 26.30^{\prime \prime} \mathrm{N}, 14^{\circ} 20^{\prime} 22.42^{\prime \prime} \mathrm{E}\right)$ were found in bycatch from fishermen's nets at 50-60 m depth, along with Posidonia leaves and maerl.

Type series are deposited in the National Museum of Natural Sciences (MNCN) in Madrid, and one specimen is kept in the Biological Reference Collections (CRB) of the Institute of Marine Science in Barcelona.

Photographs of the new species of Tambja were taken from live specimens. The specimens were first examined alive and then preserved in $96 \%$ ethanol. In the laboratory, four individuals were dissected by dorsal longitudinal incision under a dissecting microscope. Thereafter, the internal features were observed, and both the buccal mass and the reproductive system were extracted for further detailed studies. The buccal mass was put into sodium peroxide to eliminate the soft tissue. Then, the labial cuticle and radulae were examined and photographed under a dissecting microscope, and line drawings of the radulae were done with the aid of a microscope. Radulae, lateral pouches and penises were rinsed in water, dried and mounted for examination by scanning electron microscope (SEM) at the Scientific and Technical Services of the Balearic Islands University and the Autonomous University of Madrid.

Partial sequences of the mitochondrial gene cytochrome $\mathrm{c}$ oxidase subunit I (658 bp) were obtained for three specimens of $T$. mediterranea sp. nov. following the protocols of Pola et al. (2014a). The new sequences were checked for contamination with BLAST (Altschul et al. 1990) implemented in the GenBank database and added to a previous molecular dataset (Pola et al. 2014a). The best-fit models of evolution were determined using the Akaike information criterion 
(Akaike 1974) implemented in MrModeltest 2.3 (Nylander 2004). The selected models by positions were as follows: GTR $+\mathrm{I}+\mathrm{G}$ for COI-1st and COI-3rd, F81 for COI-2nd, and GTR. Bayesian inference (BI) analysis was conducted using MrBayes 3.1.2b (Ronquist and Huelsenbeck 2003) for ten million generations and four chains, with two independent runs and a sampling frequency of 1000. In order to compare the genetic distances amongst $T$. mediterranea sp. nov. and T. limaciformis, we calculated the pairwise uncorrected p-distances for COI using PAUP* 4.0b 10.0. All codon positions were considered for the analysis.

\section{Nomenclatural acts}

This published work and the nomenclatural acts it contains have been registered in ZooBank, the online registration system for the ICZN. The ZooBank LSIDs (Life Science Identifiers) can be resolved and the associated information viewed through any standard web browser by appending the LSID to the prefix "http://zoobank.org/". The LSID for this publication is urn:lsid:zoobank.org:pub:2BFE313CB8B5-4742-B7FB-7797C6627F8C.

\section{Results}

Family Polyceridae Alder \& Hancock 1845

Subfamily Nembrothinae Burn (1967)

Genus Tambja Burn, 1962

Tambja mediterranea sp. nov. (Figs. 1, 2, 3)

LSID. urn:1sid:zoobank.org:act:0B9B5A8A-551B48D5-93C6-8D92D815C236.

Type material: Holotype: MNCN 15.05/60151H. Southern Mallorca, Balearic Islands, Spain $\left(39^{\circ} 18^{\prime} \mathrm{N}, 02^{\circ} 47^{\prime} \mathrm{E}\right)$. $53 \mathrm{~m}$ depth, one adult specimen $10 \mathrm{~mm}$ long. Dissected and sequenced (GenBank accession numbers: KP793056 and KP793059 for COI and H3, respectively).

Paratypes: MNCN 15.05/60151P1, MNCN 15.05/ 60151P2 (dissected), MNCN 15.05/60151P3 (dissected), MNCN 15.05/60151P4 (dissected). $10 \mathrm{~mm}$ long. Same data as holotype.

MNCN 15.05/60152, Fomm Ir-Rih Bay, Malta $\left(35^{\circ} 54^{\prime} 26.30^{\prime \prime} \mathrm{N}, 14^{\circ} 20^{\prime} 22.42^{\prime \prime} \mathrm{E}\right) .50-60 \mathrm{~m}$ depth, one adult specimen $10 \mathrm{~mm}$ long. Sequenced (GenBank accession numbers: KP793057 and KP793060 for COI and H3, respectively).

MNCN 15.05/60153. Fomm Ir-Rih Bay, Malta $\left(35^{\circ} 54^{\prime} 26.30^{\prime \prime} \mathrm{N}, 14^{\circ} 20^{\prime} 22.42^{\prime \prime} \mathrm{E}\right) .50-60 \mathrm{~m}$ depth, one adult specimen $10 \mathrm{~mm}$ long. Sequenced (GenBank accession numbers: KP793058 and KP793061 for COI and H3, respectively).

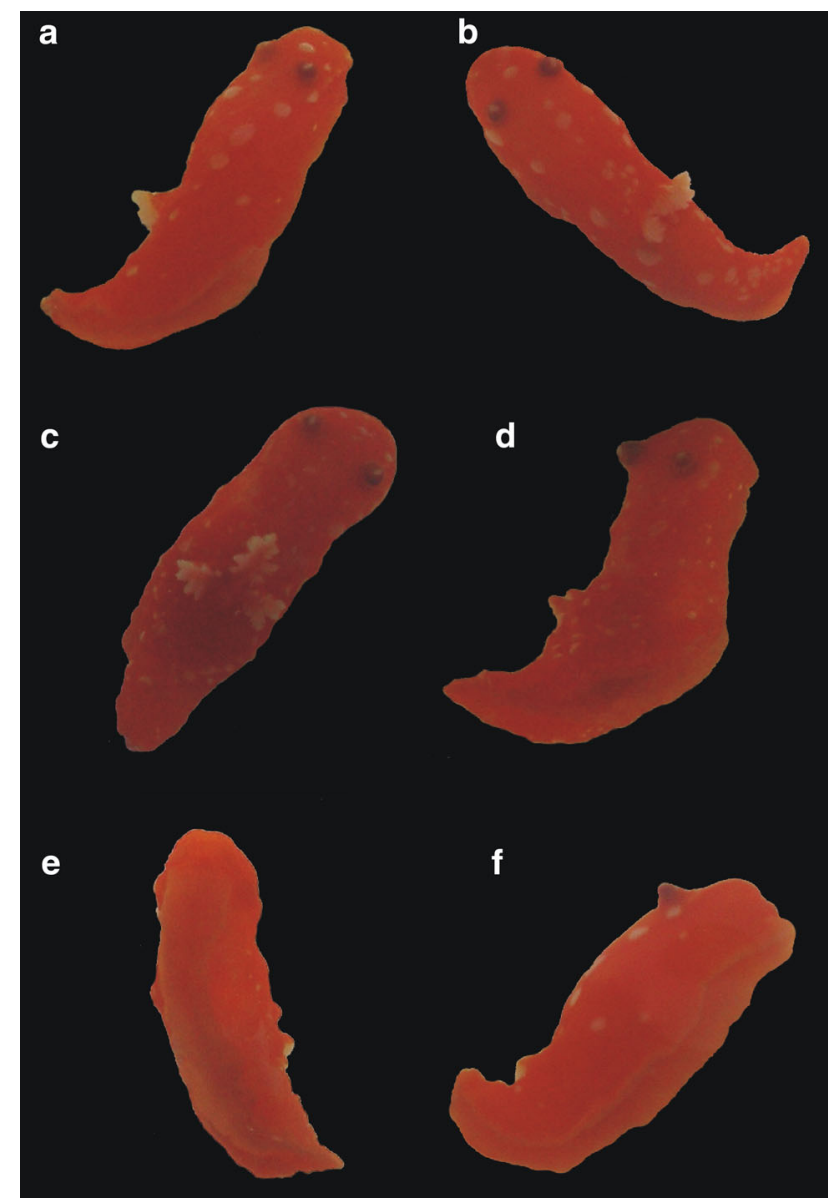

Fig. 1 Tambja mediterranea sp. nov. Photographs of living animals. a-d Dorsal view. $\mathbf{e}-\mathbf{f}$ Ventral view

Other material: CRB ICMB000001. One adult specimen $10 \mathrm{~mm}$ long. Same data and locality as type series from Mallorca.

Distribution: To date, only found in the southern continental shelf of Mallorca (Balearic Islands, Spain) and Fomm Ir-Rih Bay (Malta).

Etymology: The specific name refers to Mediterranean Sea, where the specimens were found.

Diagnosis: Body elongate and limaciform, ending in a pointed tail. Living animal up to $10 \mathrm{~mm}$ long. Ground colour orange-red (Fig. 1). Dorsum covered with rounded whitish tubercles. In some specimens, the tubercles are large and most of them arranged in three rows along the body (Fig. 1a, b). In others, the tubercles are smaller and irregularly scattered over the dorsum (Fig. 1c, d). Head rounded anteriorly, with a pair of perfoliate rhinophores with about 15-20 lamellae, retractile in elevated sheaths. Rhinophores dark red coloured with whitish tip. Oral tentacles short and grooved. Three tripinnate gill branches, non-retractile, with orange-reddish rachis and whitish 
Fig. 2 Tambja mediterranea sp. nov. SEM (a-c, e-j) and binocular dissecting scope micrographs (d). a Oral tube with lateral pouches $(\mathrm{MNCN}$ $15.05 / 60151 \mathrm{H})$. b Lateral pouch (MNCN 15.05/60151H).

c Radula (MNCN 15.05/ 60151P3). d Central part of the radula showing the weak rachidian tooth (MNCN 15.05/ 60151P3). e Right half of the radula (MNCN 15.05/60151H). f Detail of innermost lateral teeth (MNCN 15.05/60151P3). g-j Penial spines. g Distal penial spines (MNCN 15.05/ 60151H). h Detail of the distal penial spines (MNCN 15.05/ $60151 \mathrm{H})$. i Basal penial spines (MNCN 15.05/60151P3).

j Detail of the rare spines (MNCN 15.05/60151P3). Scale bar a $1 \mathrm{~mm}, \mathbf{b} 300 \mu \mathrm{m}, \mathbf{c} 1 \mu \mathrm{mm}$, d $200 \mu \mathrm{m}$, e $500 \mu \mathrm{m}$, f $500 \mu \mathrm{m}$, g $50 \mu \mathrm{m}, \mathbf{h} 20 \mu \mathrm{m}, \mathbf{i} 500 \mu \mathrm{m}$, j $10 \mu \mathrm{m}$
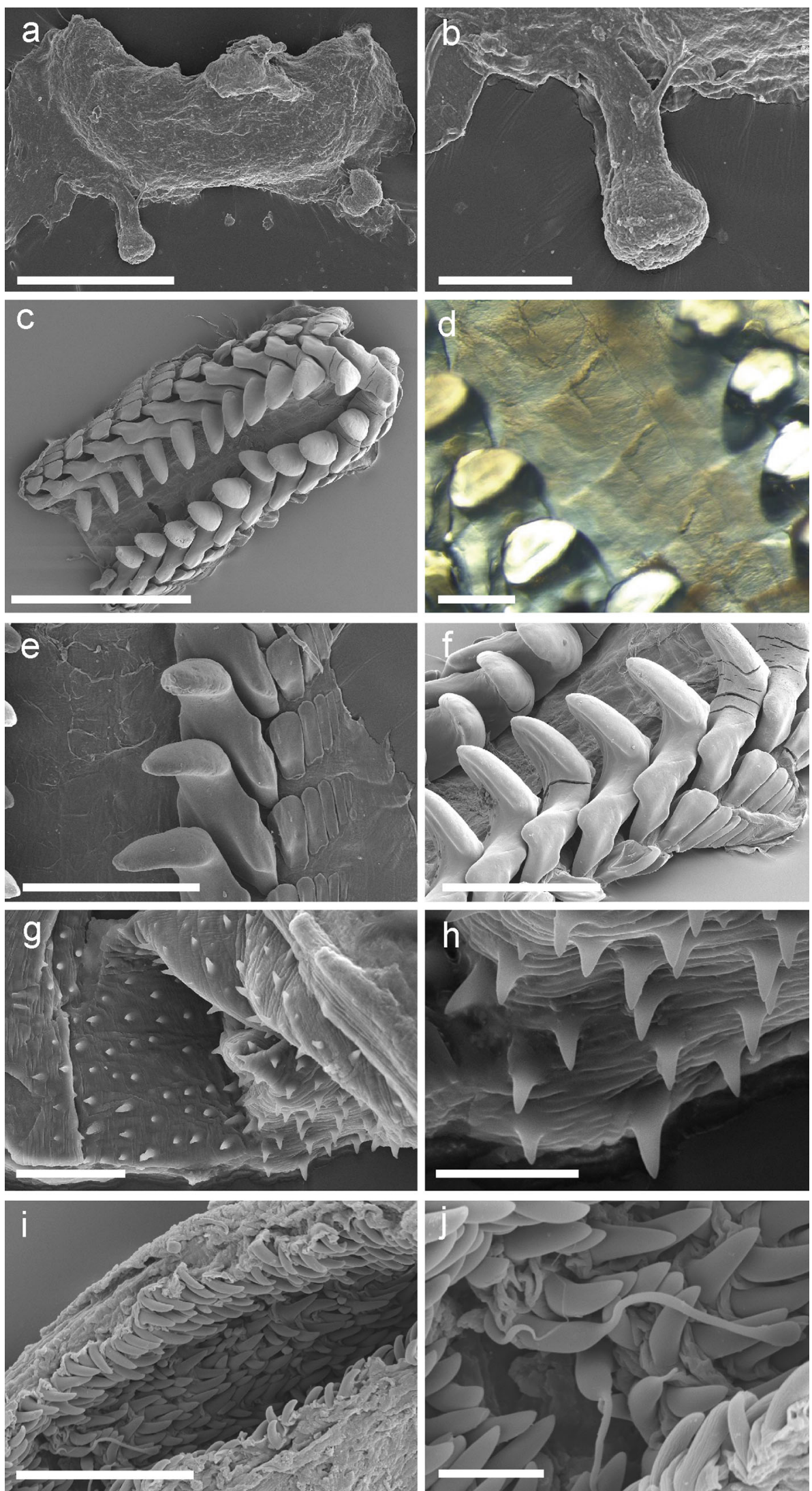
Fig. 3 Reproductive system of T. mediterranea sp. nov. am ampulla, $b c$ bursa copulatrix, fglm female gland mass, $g a$ genital atrium, $h d$ hermaphrodite duct, $p r$ prostate, $r s$ receptaculum seminis, $v a$ vagina, $v d$ vas deferens. Scale bar $1 \mathrm{~mm}$

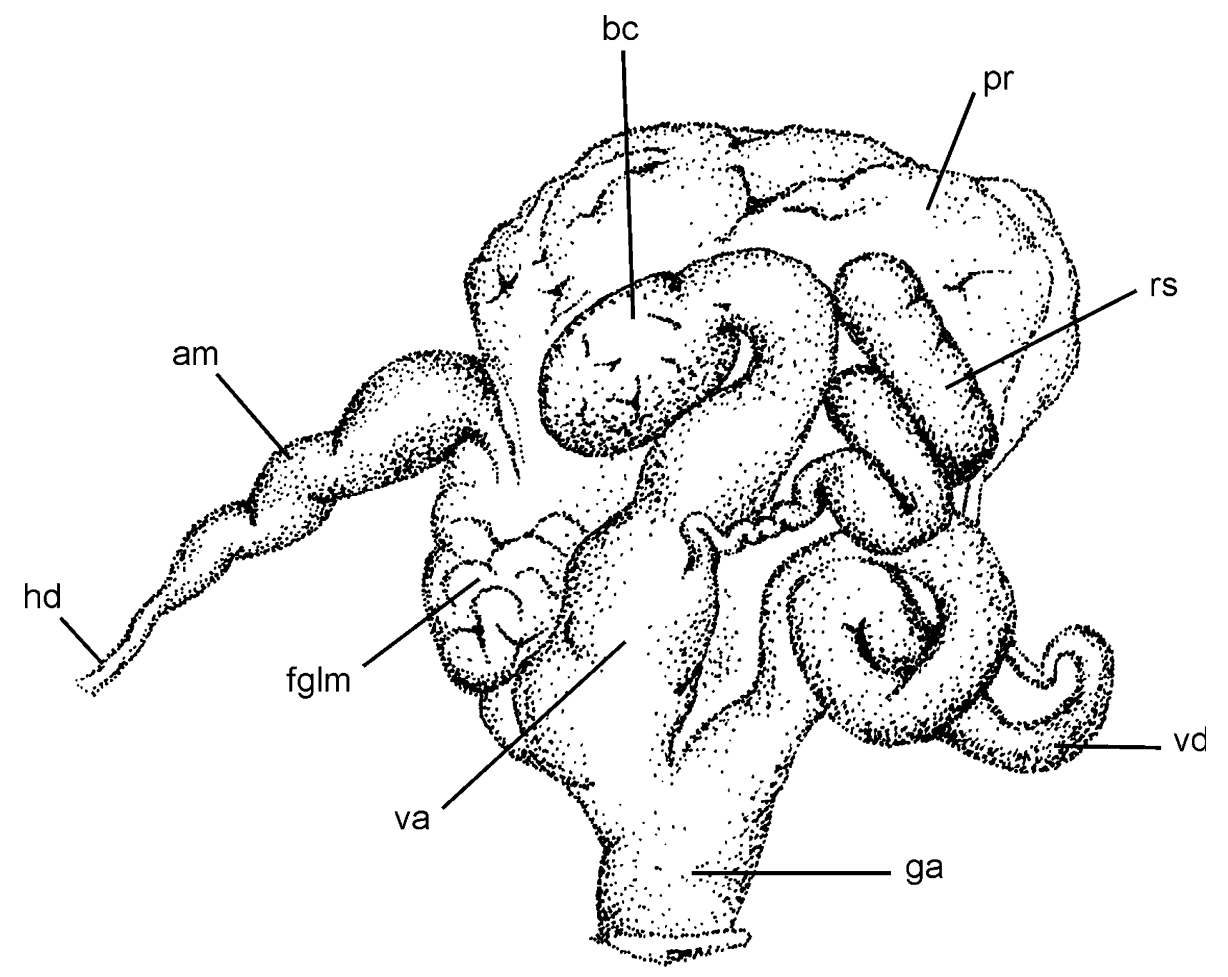

branches. Lateral slots below the rhinophores. Foot and oral tentacles orange-red (Fig. 1e, f).

Internally, a short muscular oral tube continues into the buccal mass. There is a pair of small, elongate lateral pouches at the junction of the oral tube and the buccal mass (Fig. 2a, b). Labial cuticle chitinous, smooth and very thin. Radular formula of the dissected specimens 9-13 × 6-5.1.1.1.5-6 (Fig. 2c). Rachidian teeth subquadrate without denticles and smooth, slightly curved upper margin, very thin and weak (Fig. 2d, e). Rachidian teeth are very difficult to see when the radula is dried (Fig. 2c, e, f). Innermost lateral tooth elongate and large with two cusps: upper cusp hamate, well developed, with a rounded prominence on the outer side of the tooth; and outer cusp small. A wide body joins both cusps (Fig. 2e, f). The remaining lateral teeth are represented by $5-6$ rectangular plates with rounded edges (Fig. 2e, f). The innermost plate has a rounded prominence on the inner side, as if it were a vestigial cusp axe-shaped. The next plates are oval-shaped and become progressively smaller towards the outer margin.

The reproductive system is triaulic (Fig. 3). The elongate and narrow hermaphrodite duct continues into a large, wide and folded ampulla, which is divided into a short oviduct and the vas deferens. The oviduct enters the female gland. The vas deferens widens into a very large, coiled massive prostate. Next to the prostate is the female gland mass. The prostatic section of the vas deferens narrows again to a thin duct, which descends through the centre of the large, wider and highly convoluted final portion of the vas deferens. In situ, the bursa copulatrix is almost entirely wrapped by the prostate. The penis is located on the larger muscular portion of the vas deferens, covered with two different types of spines. Scattered distal spines are short and broad (Fig. 2g, h), some of them very small (Fig. 2g); the remaining spines are numerous and closely packed; they are elongate, thick and slightly curved (Fig. 2h, i). One specimen has some unusual spines, which have an elongate narrow lengthening structure and rounded distal part (Fig. 2i, j). These latter spines are located on the basal part of the penis. The bursa copulatrix is large and round. The seminal receptacle is elongate, wide and longer than the bursa copulatrix. The seminal receptacle joins the vagina by a long and highly convoluted duct. The vagina is large and wide and leads to the genital atrium next to the vas deferens. There is no vaginal gland.

\section{Discussion}

The genus Tambja includes numerous species distributed worldwide, but only two species known from European waters: Tambja ceutae García-Gómez and Ortea 1988 and Tambja marbellensis Schick and Cervera 1998. Tambja ceutae has been recorded from the Strait of Gibraltar (Ceuta), southern Andalusia, Madeira, Azores and the Canary Islands (Pola et al. 2006a), while T. marbellensis is found in southern Spain and Portugal (Pola et al. 2006a). 
Fig. 4 Phylogenetic hypothesis based on COI sequences represented by Bayesian inference. Numbers represent posterior probabilities from Bayesian inference

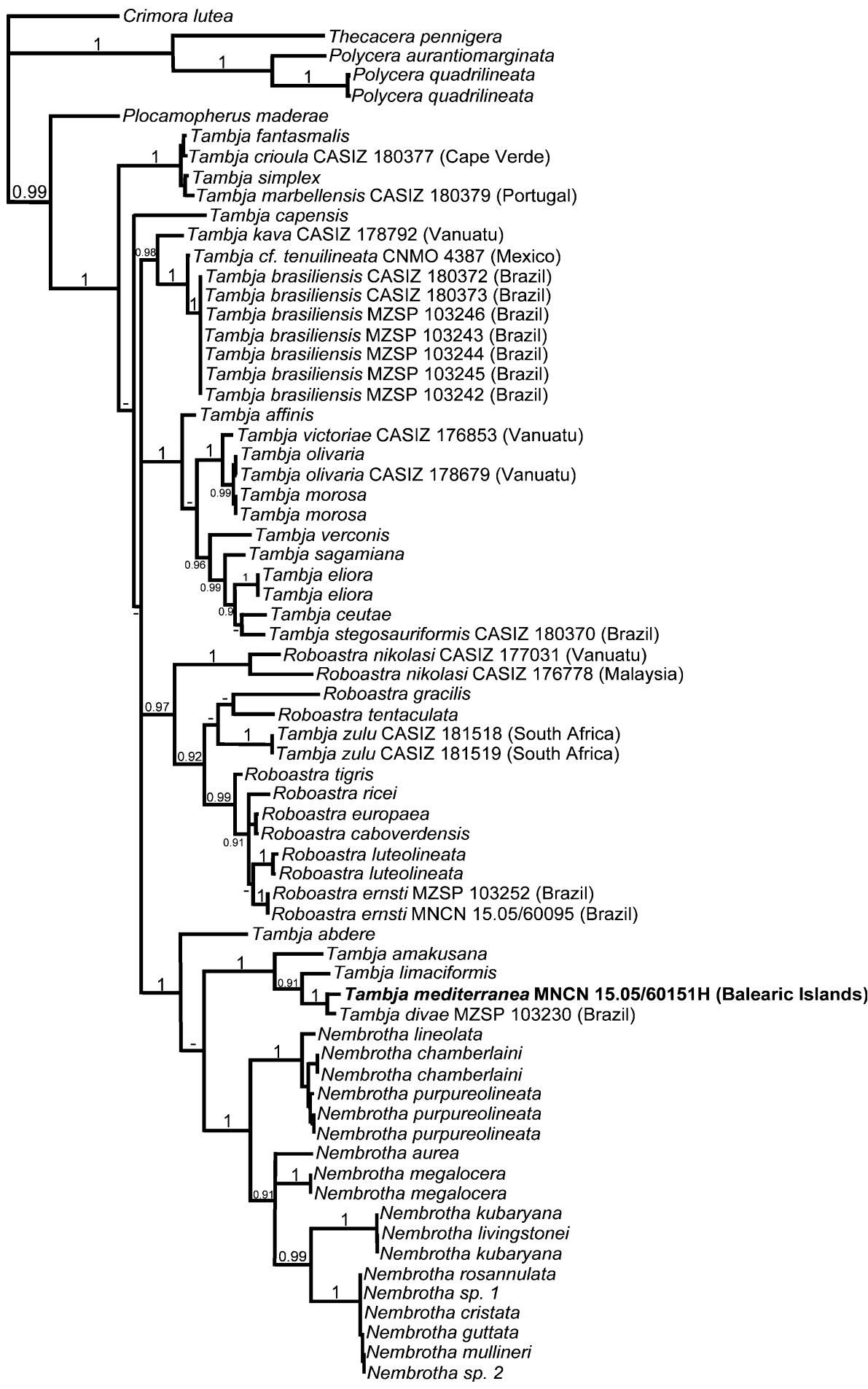

The presence of this genus in the Mediterranean Sea is restricted to the Alboran Sea, and to date, no species of Tambja has been recorded further east in the Mediterranean. Both Mediterranean species clearly differ in their external features from the new species. Tambja mediterranea sp. nov. has an orange-red notum with rounded whitish tubercles, while $T$. ceutae has a green-blue ground colour with longitudinal yellow bands and small conic papillae around the notum (García-Gómez and Ortea 1988) and T. marbellensis is dark blue or dark green-blue with several yellow stripes and marks shaded with brown (Schick and Cervera 1998).

The species most similar to T. mediterranea sp. nov. is T. limaciformis, described by Eliot (1908) from the Red 
Sea. Both species share several morphological and anatomical features. Externally, T. limaciformis resembles the new species as it has a deep saffron-red ground colour with small yellowish to white dots scattered on the back and the sides of the body. However, the presence of purple on the tips of the rhinophores and the tips of the gill is distinctive in T. limaciformis (Baba 1960; Pola et al. 2006a). The radular teeth are quite similar, the central tooth is subquadrate without denticles, first lateral tooth large and elongate with upper cusp hamate and well developed, but all specimens of $T$. mediterranea sp. nov. studied have a very thin rachidian tooth. These teeth are difficult to see and at a cursory glance seem to be lacking. Also, Pola et al. (2006a) described the presence of a vestigial tooth between the rachidian and the inner lateral for $T$. limaciformis. In $T$. mediterranea sp. nov., the vestigial teeth are lacking or at least much less well developed than in T. limaciformis.

Regarding the reproductive system, both species are very similar, but $T$. limaciformis has three different kinds of penial spines (Pola et al. 2006a), whereas T. mediterranea sp. nov. has only two of them. Moreover, their shape and number differ from those of T. limaciformis, which has smaller and sharper spines, which are less closely packed than in T. mediterranea sp. nov. The number of spines in $T$. mediterranea sp. nov. is significantly greater.

In summary, there is no doubt that the only species quite similar to T. mediterranea sp. nov. is T. limaciformis. However, T. limaciformis has been reported from the Red Sea, Japan, Papua New Guinea, Philippines, Mariana Islands, Hawaii, Western Australia and Heron Island, but never from the Atlantic or Mediterranean waters (Pola et al. 2006a). Finally, in order to discard the possibility that T. mediterranea sp. nov. is actually T. limaciformis introduced through the Suez Canal, we obtained COI sequences for three specimens of T. mediterranea sp. nov. and compared them with $T$. limaciformis from Pola et al. (2007) (GenBank accession number: EF142878.1). In this case, the minimum uncorrected p-distance for COI between $T$. mediterranea sp. nov. and T. limaciformis was $11.0 \%$. Since there are no available sequences of $\mathrm{H} 3$ for $T$. limaciformis, this gene has not been used here.

The distribution together with some external and internal differences and the minimum uncorrected p-distance for $\mathrm{COI}$ allow us to describe the first species of the genus for the Balearic Islands and Malta.

In addition, it is clear that $T$. mediterranea sp. nov. shares several important features with only some "Tambja" s.l. Burn, 1962 (Table 1). Only five other species of the genus described to date lack a vaginal gland, i.e. T. limaciformis, $T$. amakusana, $T$. abdere, $T$. divae and $T$. blacki. These same five species are the only ones with the bursa copulatrix surrounded in situ by the prostate, and all but $T$. abdere have a large and wide vagina. In the case of
T. abdere, the vagina is much narrower, long and coiled (Pola et al. 2006b). Some other interesting features are present only in T. mediterranea sp. nov. and a few of the latter species. In fact, only T. limaciformis, T. amakusana and $T$. divae have small, elongate pouches opening at the junction of the oral tube and the buccal mass. The function of these structures is still unknown. Finally, only $T$. limaciformis, T. amakusana and $T$. capensis have vestigial teeth between the rachidians and the inner laterals. In the case of T. mediterranea sp. nov., it is not clear whether these vestigial teeth are really present. Since the rachidian teeth are so thin and weak, we might have failed to notice them, but in the other mentioned species these teeth are always clearly visible.

All these peculiar morphological features especially shared by $T$. limaciformis and T. amakusana probably make that these two species clustered together in a very wellsupported clade (Pola et al. 2006a, 2007, 2008). In fact, $T$. divae was not included in Pola et al. $(2007,2008)$ because the specimens were missing, but it is included in Pola et al. (2014a) and it clusters together with T. limaciformis and $T$. amakusana. Molecular sequences for several genes are still missing for some species such as T. blacki, but the morphological and molecular analyses so far clearly show that T. limaciformis, T. amakusana and T. divae are grouped together and well as are T. abdere and T. blacki. When including COI sequence for T. mediterranea sp. nov. in the molecular dataset of Pola et al. (2014a), T. mediterranea sp. nov. clusters together with maximum support $(\mathrm{PP}=1.00)$ with T. limaciformis, T. amakusana and T. divae (Fig. 4).

Material from further oceanographic surveys will help us to continue unravelling the intricate phylogenetic relationships of this group of sea slugs.

Acknowledgments The specimens studied in this paper were collected with the help of all the participants in the oceanographic survey DRAGONSAL-0712, especially Carmen Barberá, Marta DíazValdés, Aina de Mesa, Francesc Ordinas, Concepció Rodríguez-Prieto, María Valls and Eva $\mathrm{M}^{\mathrm{a}}$ Vidal, who sorted the benthos samples. We are very grateful to Constantine Mifsud for collecting the specimens from Malta. The cruise was developed on board of the RV Ramón Margalef. The building of this oceanographic vessel was partly financed by the Programme FEDER, FICTS-2011-03-01. Our sincere gratitude goes to Juan Lucas Cervera for his valuable help identifying the genus and for his useful comments. We are also indebted to Jazmín Ortigosa for sequencing the specimens at the University of Cádiz. The sequences were obtained thanks to the research grant CGL2010-17187 of the Spanish Ministry of Economy and Competitiveness to Juan Lucas Cervera. We are grateful to Ferran Hierro and Enrique Rodríguez for providing the scanning electron microscopy facilities in the Scientific and Technical Services of the University of Balearic Islands and in the Autonomous University of Madrid, respectively. The present paper is framed within the project FEP311NBAL00001 "DRAGONSAL", supported by the Conselleria d'Agricultura, Medi Ambient i Territori de les Illes Balears, the Spanish Oceanographic Institute and the European Fisheries Fund (FEP). We are grateful to Eve Galimay for her English correction. 


\section{References}

Akaike H (1974) A new look at the statistical model identification. IEEE Trans Automat Contr 19:716-723

Altschul SF, Gish W, Miller W, Myers EW, Lipman DJ (1990) Basic local alignment search tool. J Mol Biol 215:403-410

Baba K (1960) The genera Gymnodoris and Nembrotha from Japan (Nudibranchia-Polyceridae). Publ Seto Mar Biol Lab 8:71-75

Baba K (1987) Two new green-colored species of Tambja from Japan (Nudibranchia: Polyceridae). Venus Jap Jour Malac 46:13-18

Burn R (1967) Notes on an overlooked nudibranch genus, Roboastra Bergh, 1877, and two allied genera (Mollusca:Gastropoda). Aust Zool 14:212-222

Cervera JL, Calado G, Gavaia C, Malaquias MAE, Templado J, Ballesteros M, García-Gómez JC, Megina C (2004) An annotated and updated checklist of the opisthobranchs (Mollusca: Gastropoda) from Spain and Portugal (including islands and archipelagos). Bol Inst Esp Oceano 20:1-122

Cobb G, Willan R (2006) Undersea jewels - a colour guide to nudibranchs. Australian Biological Resources Study, Canberra

Coleman N (2008) Nudibranch encyclopedia. Neville Coleman's Underwater Geographic Pty, National Library of Australia, Springwood

Debelius H, Kuiter RH (2007) Nudibranchs of the world. IKANUnterwasserarchiv, Frankfurt

Eliot C (1908) Reports on the Marine Biology of the Sudanese Red Sea. XI. Notes on a collection of Nudibranchs from the Red Sea. J Linn Soc Lond 31:86-122

García-Gómez JC, Ortea J (1988) Una nueva especie de Tambja Burn, 1962 (Mollusca Nudibranchia). Bull Mus Nac Hist Nat 4th Series 10: 301-307

Gosliner TM, Behrens DW, Valdés A (2008) Indo-Pacific nudibranchs \& sea slugs. A field guide to the world's most diverse fauna. Sea Challengers Natural History Books, Gig Harbor

Nakano R (2004) Opisthobranchs of Japan Islands. Rutles, Inc., Tokyo
Nylander JAA (2004) MrModeltest v2.3. Program distributed by the author. Evolutionary Biology Centre, Uppsala University

Pola M, Cervera JL, Gosliner TM (2006a) Taxonomic revision and phylogenetic analysis of the genus Tambja Burn, 1962 (Mollusca, Nudibranchia, Polyceridae). Zool Scr 35:491-530

Pola M, Vallés Y, Cervera JL, Medina M, Gosliner TM (2006b) Taxonomic status of Tambja abdere and Tambja fusca based on morphological and molecular evidence, with comments on the phylogeny of the subfamily Nembrothinae (Nudibranchia: Polyceridae). Ann Bot Fenn 43:52-64

Pola M, Cervera JL, Gosliner TM (2006c) Description of two new phanerobranch nembrothid species (Nudibranchia: Polyceridae: Doridacea). J Mar Biol Ass UK 86:403-409

Pola M, Cervera JL, Gosliner TM (2007) Phylogenetic relationships of Nembrothinae (Mollusca: Doridacea: Polyceridae) inferred from morphology and mitochondrial DNA. Mol Phylogenet Evol 43:726-742

Pola M, Cervera JL, Gosliner TM (2008) Description of the first Roboastra species (Nudibranchia, Polyceridae, Nembrothinae) from the western Atlantic. Bull Mar Sci 83:391-399

Pola M, Roldán P, Padilla S (2014a) Molecular data on the genus Okenia (Nudibranchia: Goniodorididae) reveal a new cryptic species from New South Wales (Australia). J Mar Biol Ass UK 94:587-598

Pola M, Padula V, Gosliner TM, Cervera JL (2014b) Going further on an intricate and challenging group of nudibranchs-description of five new species and a more complete molecular phylogeny of the subfamily Nembrothinae (Polyceridae). Cladistics 30:607-634

Ronquist F, Huelsenbeck JP (2003) MrBayes 3: Bayesian phylogenetic inference under mixed models. Bioinformatics 19:1572-1574

Schick K-L, Cervera JL (1998) Description of a new species in the genus Tambja Burn, 1962 (Gastropoda: Nudibranchia: Polyceratidae) from southern Spain. Veliger 41:344-350 